\title{
Enhancement of Damage to Escherichia coli Strain B/R after Ultraviolet and $\gamma$ Irradiation
}

\author{
By A. J. FORAGE* AND N. E. GILLIES \\ Department of Biology as Applied to Medicine, \\ The Middlesex Hospital Medical School, London, W.I
}

(Accepted for publication ro September 1969)

\begin{abstract}
SUMMARY
Death of Escherichia coli after exposure to ultraviolet (u.v.) radiation or to $\gamma$-rays was markedly increased when the bacteria were incubated on media containing chloramphenicol or puromycin. A similar effect occurred when an irradiated histidine-requiring strain of $E$. coli $\mathrm{B} / \mathrm{R}$ was deprived of its requirement but not when several other amino acid auxotrophic mutants of $E$. coli $B / \mathbf{R}$ were similarly deprived. The extra killing may be associated with the synthesis of RNA rather than be a direct consequence of inhibition of protein synthesis.
\end{abstract}

\section{INTRODUCTION}

Death (i.e. the inability to form a visible colony) in Escherichia coli strain B/R after exposure to ultraviolet (u.v.) or ionizing radiation depends partly on the conditions in which the bacteria are treated after irradiation. For example, a marked decrease in survival occurs when the bacteria are incubated on a nutrient medium containing chloramphenicol for a short period after irradiation (Okagaki, I960; Alper, 1963; Gillies \& Brown, 1967). This effect is apparently caused by inhibition of protein synthesis in the irradiated bacteria; there is some evidence that it may result from loss of substances which are not resynthesized (Gillies \& Brown, 1967). In the present paper data are presented on the effect on survival of irradiated $E$. coli $\mathrm{B} / \mathrm{R}$ of puromycin, which inhibits protein synthesis (Yarmolinsky \& de la Haba, 1959), of laevorphanol, which inhibits the uptake of $\left[{ }^{14} \mathrm{C}\right]$ uracil into bacterial RNA (Simon, 1963), and of withholding a required amino acid from auxotrophic strains.

\section{METHODS}

Strains. The strain Escherichia coli $\mathrm{B} / \mathrm{R}$ was that used previously by Alper \& Gillies (I960). Mutants auxotrophic for amino acids were isolated from this strain by using methods described by Gillies (I96I):

\begin{tabular}{|c|c|c|}
\hline Mutant & Requirement & No. of mutants \\
\hline E. coli $\mathrm{B} / \mathrm{R}$ his $^{-}$ & Histidine & 3 \\
\hline E. coli $\mathbf{B} / \mathbf{R} 7$ & Proline & I \\
\hline E. coli $\mathrm{B} / \mathrm{R} \mathrm{met}^{-}$ & Methionine & $\mathbf{I}$ \\
\hline E. coli $\mathrm{B} / \mathrm{R}$ trp - & Tryptophan & $\mathbf{I}$ \\
\hline
\end{tabular}

Stock cultures were maintained at $4^{\circ}$ on slopes of Oxoid Blood Agar Base.

* Present address: Medical Research Council, Experimental Radiopathology Unit, Hammersmith Hospital, Ducane Road, London, W. 12. 
Media. All strains were grown to stationary phase in Oxoid nutrient broth at $37^{\circ}$. For colony counting after irradiation Escherichia coli $\mathbf{B} / \mathbf{R}$ was incubated at $37^{\circ}$ on Oxoid Blood Agar Base or on a defined nutrient medium known as M I9 (Forage \& Gillies, 1964). The irradiated auxotrophic mutants were incubated on medium M 19, from which the required amino acid was omitted as desired.

Various substances were added to the post-irradiation growth medium where indicated. Chloramphenicol was heat-sterilized and added at $5 \mu \mathrm{g} . / \mathrm{ml}$. Puromycin was sterilized by filtration through an Oxoid membrane filter (pore size not greater than $\mathrm{I} \mu$ ) and added at $40 \mu \mathrm{g} . / \mathrm{ml}$. Laevorphanol was heat-sterilized and used at $\mathrm{I} \cdot 2 \mathrm{mg} . / \mathrm{ml}$.

Extraction and measurement of protein containing $\left[{ }^{14} \mathrm{C}\right]$ leucine and of $R N A$ containing $\left[{ }^{14} \mathrm{C}\right]$ uracil. The rates of protein synthesis and of RNA synthesis were determined by measuring the incorporation of $\left[{ }^{14} \mathrm{C}\right]$ leucine (purity, $99 \%$; specific activity, $6.6 \mathrm{mc}$ / m-mole) and $\left[{ }^{14} \mathrm{C}\right]$ uracil (purity, $99 \%$; specific activity, $40.6 \mathrm{mc} / \mathrm{m}$-mole) into protein and RNA respectively. Both labelled compounds were obtained from the Radiochemical Centre, Amersham, Bucks. Radioactive samples were counted in a Tri-Carb liquid Scintillation Counting System, Model $314 \mathrm{Ex}$, set at 3.3 high voltage.

Bacteria were grown to stationary phase, centrifuged and resuspended in about $8 \mathrm{ml} . \mathrm{M} / \mathrm{I} 5, \mathrm{pH} 7, \mathrm{Na} / \mathrm{K}$ phosphate buffer at $10^{8}$ organisms $/ \mathrm{ml}$, , and $5 \mathrm{ml}$. of the irradiated suspension were inoculated into $50 \mathrm{ml}$. medium $\mathrm{M} 19$ containing $0.2 \mu \mathrm{C}$ of $\left[{ }^{14} \mathrm{C}\right]$ leucine or $0.02 \mu \mathrm{C} / \mathrm{ml}$. of $\left[{ }^{14} \mathrm{C}\right]$ uracil. At intervals, $4 \mathrm{ml}$. samples were removed and pipetted into $0.5 \mathrm{ml} .50 \%$ ice-cold trichloroacetic acid (TCA) and filtered through a Millipore membrane filter (GSWP 02500 , pore size $0.22 \mu$, diameter $25 \mathrm{~mm}$.). The precipitate was washed four times with $4 \mathrm{ml} .5 \%$ ice-cold TCA, and the filter dried at $37^{\circ}$ for $\mathrm{I} \mathrm{hr}$. When completely dry, the filter was placed in the bottom of a scintillation bottle and $4 \mathrm{ml}$. of scintillator ( $5 \mathrm{~g}$. 2,5 diphenyloxazole and 0.3 g. I,4 bis-2-(4-methyl5-phenyl-oxazoly)-benzene dissolved in I 1 . scintillation-grade toluene) were added.

Irradiation experiments. Bacteria were washed three times and resuspended in phosphate buffer for irradiation.

Ultraviolet irradiation. Ten ml. suspension were pipetted into a $9 \mathrm{~cm}$. glass Petri dish and placed under a water-jacketed Hanovia I5 W u.v. germicidal lamp emitting more than $90 \%$ of its energy at $2537 \AA$. The energy emitted from the lamp was $286 \mathrm{ergs} /$ $\mathrm{mm} .{ }^{2} / \mathrm{min}$. at $42 \mathrm{~cm}$. The dish was gently shaken during irradiation, after which the suspension was diluted and plated away from direct light.

$\gamma$-Irradiation. Bacteria were exposed to $\gamma$-irradiation from a ${ }^{60} \mathrm{Co}$ source (VickersArmstrong Mk IV Hotspot Irradiation Unit) in the vessel described by Forage \& Gillies (1964), with oxygen-free nitrogen bubbled through the suspension. The dose rate in the ${ }^{60} \mathrm{Co}$ unit, as measured by ferrous sulphate dosimetry (Miller \& Wilkinson, I952), was $2 \cdot 2 \mathrm{krads} / \mathrm{min}$.

Dilutions of unirradiated and irradiated bacterial suspensions were dispensed with an Agla microsyringe (Burroughs Wellcome Co., London) on to cellophan carriers $(2 \times \mathrm{I}$ in.; $5 \times 2.5 \mathrm{~cm}$.) lying on the surface of the growth medium previously warmed to $37^{\circ}$. Bacteria could thus be transferred rapidly from one medium to another (Alper \& Gillies, I958).

Although in most of the experiments the cellophan technique was used, the investigations with laevorphanol were made in liquid media. Unirradiated and irradiated bacteria were inoculated into bottles containing $19 \mathrm{ml}$. nutrient broth containing 
laevorphanol or chloramphenicol, incubated and at intervals samples for the determination of the viable count were removed, diluted and plated on to nutrient agar. In both procedures the plates were incubated overnight at $37^{\circ}$ and macro-colonies scored.

\section{RESULTS}

\section{Relationship between protein synthesis and survival in Escherichia coli $B / R$}

Puromycin and chloramphenicol. After exposure of the bacteria to u.v. radiation the two antibiotics caused additional killing to the same extent (Fig. I). After exposure to a dose of $\gamma$-rays, which caused the same killing as u.v. radiation, both antibiotics decreased survival to about one-third. These results suggest that the decrease in survival may be caused by general inhibition of protein synthesis, with which puromycin and chloramphenicol interfere (Morris \& Schweet, I96I; Jardetzky \& Julian, 1964).

A difficulty in the use of supposedly specific inhibitors is that they may cause other unknown effects in the organism. To overcome this problem we have studied the effect on survival of withholding the required amino acid from irradiated auxotrophic mutants of Escherichia coli $\mathrm{B} / \mathrm{R}$. Under these conditions protein synthesis would be expected not to occur or to be strictly limited.

Histidine-requiring auxotrophs. When Escherichia coli $\mathrm{B} / \mathrm{R}^{-}$his $^{-}$was incubated on a defined nutrient medium lacking histidine immediately following $\gamma$-irradiation under anaerobic conditions, survival was decreased to about the same as by chloramphenicol (Fig. 2). A series of experiments in which different doses of $\gamma$-rays were used are summarized in the survival curves shown in Fig. 3. Qualitatively similar results were obtained for u.v.-irradiated bacteria although the enhancement of death was only half as much as that found when they were treated with chloramphenicol. Two other histidine-requiring mutants, isolated on different occasions, responded in similar fashion.

Proline-requiring auxotroph. After $\gamma$-irradiation under anaerobic conditions no decrease in survival was observed when Escherichia coli $\mathrm{B} / \mathrm{R} 7$ was incubated for a period on medium M 19 lacking proline. After u.v.-irradiation, however, there was an increase in colony-forming ability following incubation without proline (Fig. 4).

Methionine-requiring and tryptophan-requiring auxotrophs. There was a small but insignificant decrease in the survival when cells of Escherichia coli $\mathrm{B} / \mathrm{R} \mathrm{met}^{-}$and $E$. coli $\mathrm{B} / \mathbf{R}$ trp $^{-}$were incubated on media lacking their requirement after exposure to relatively large doses of $\gamma$-rays. There was no additional killing when the bacteria were similarly treated after u.v.-irradiation.

Protein synthesis in Escherichia coli $B / R$. It is difficult to account for the difference in survival of the histidine-requiring strain compared with the other amino acid auxotrophs. In each strain a decrease in survival might have been expected since the results with chloramphenicol and puromycin suggested that, when protein synthesis is inhibited in $E$. coli $\mathrm{B} / \mathrm{R}$, survival is decreased. However, because of possible variation in the sizes of amino acid pools and the rates at which the amino acids are utilized, cessation of protein synthesis may occur more rapidly in some auxotrophs than in others. Strains of E.coli $\mathrm{B} / \mathrm{R}$ which had been exposed to u.v.-irradiation incorporated

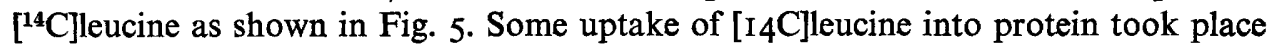
in all the auxotrophic strains and also in bacteria treated with puromycin. Only in bacteria treated with chloramphenicol did synthesis of protein not occur. Qualitatively 
similar results were found for $\gamma$-irradiated bacteria. Thus protein synthesis occurred in bacteria treated with puromycin or in $E$. coli $\mathrm{B} / \mathrm{R}$ his $^{-}$under conditions which caused additional death, whilst no protein synthesis occurred in bacteria treated with chloramphenicol, a condition which also caused additional death. Protein was synthesized to a similar extent in all the auxotrophs deprived of their requirement, yet only in the histidine-requiring strain did an appreciable decrease in survival occur.

Since these results showed no obvious correlation between survival and protein

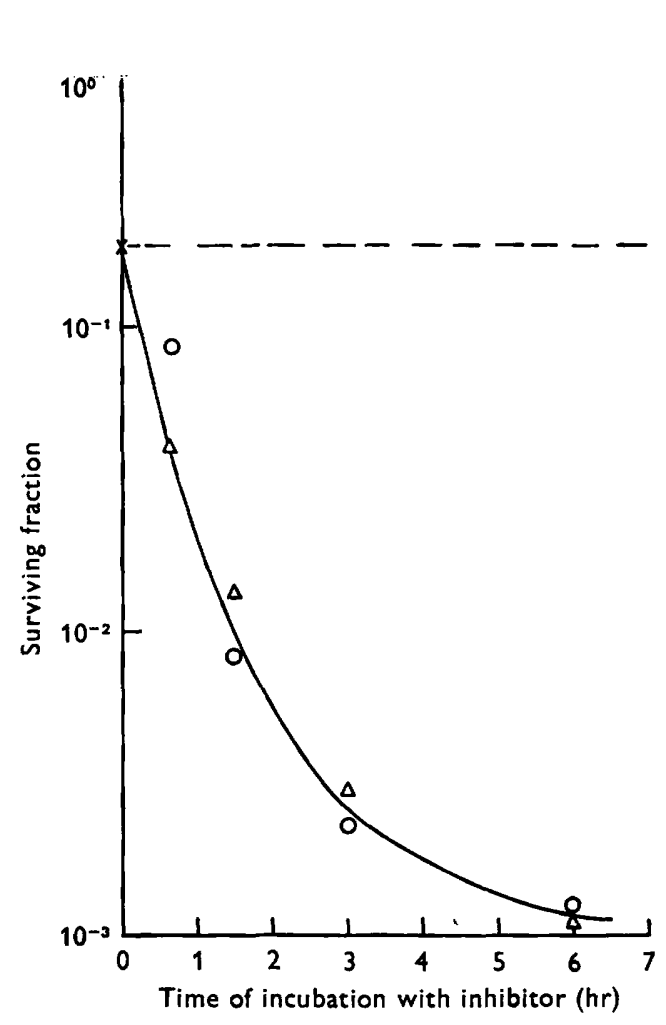

Fig. I

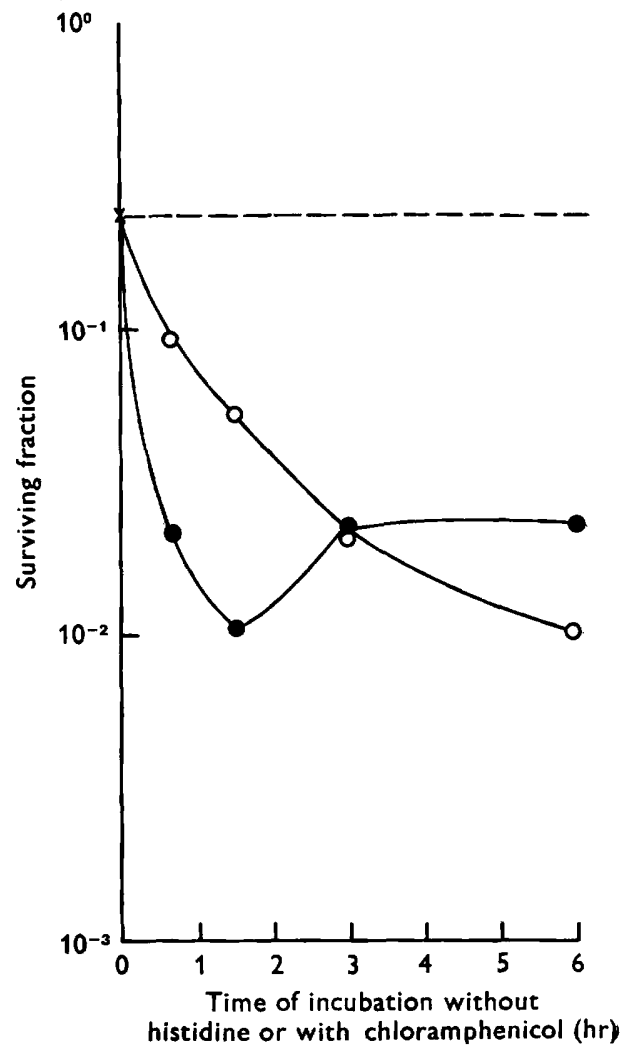

Fig. 2

Fig. I. Survival of stationary phase Escherichia coli $B / R$ after exposure to u.v. radiation (I80 ergs $/ \mathrm{mm}^{2}$ ). $\times$, Survival of bacteria incubated throughout on Oxoid Blood Agar Base. Survival of bacteria incubated on first medium for the intervals indicated before transfer to second medium:

Ist medium 2nd medium
$\triangle$ Oxoid Blood Agar Base + puromycin
$\rightarrow$ Oxoid Blood Agar Base
0 Oxoid Blood Agar Base + chloramphenicol $\rightarrow$ Oxoid Blood Agar Base

Fig. 2. Survival of stationary phase Escherichia coli strain $\mathbf{B} / \mathbf{R}$ his ${ }^{-}$after exposure to $\gamma$-rays (99 krads) under anaerobic conditions. $\times$, Survival of bacteria incubated throughout on medium M $19+$ histidine. Survival of bacteria incubated on first medium for the intervals indicated before transfer to second medium:

Ist medium

O M 19

- M I9+histidine+ chloramphenicol $\rightarrow$ M r9+histidine 2nd medium

$\rightarrow$ M I9+histidine 
synthesis in Escherichia coli $\mathbf{B} / \mathbf{R}$, we examined the effect of these post-irradiation conditions on RNA synthesis in bacteria. Both puromycin and chloramphenicol, whilst inhibiting protein synthesis, lead to the accumulation of RNA in bacteria (Yarmolinsky \& de la Haba, 1959; Nomura \& Watson, 1959). It is possible, therefore, that additional death caused by post-irradiation treatments might be due to the accumulation of RNA in the irradiated bacteria.

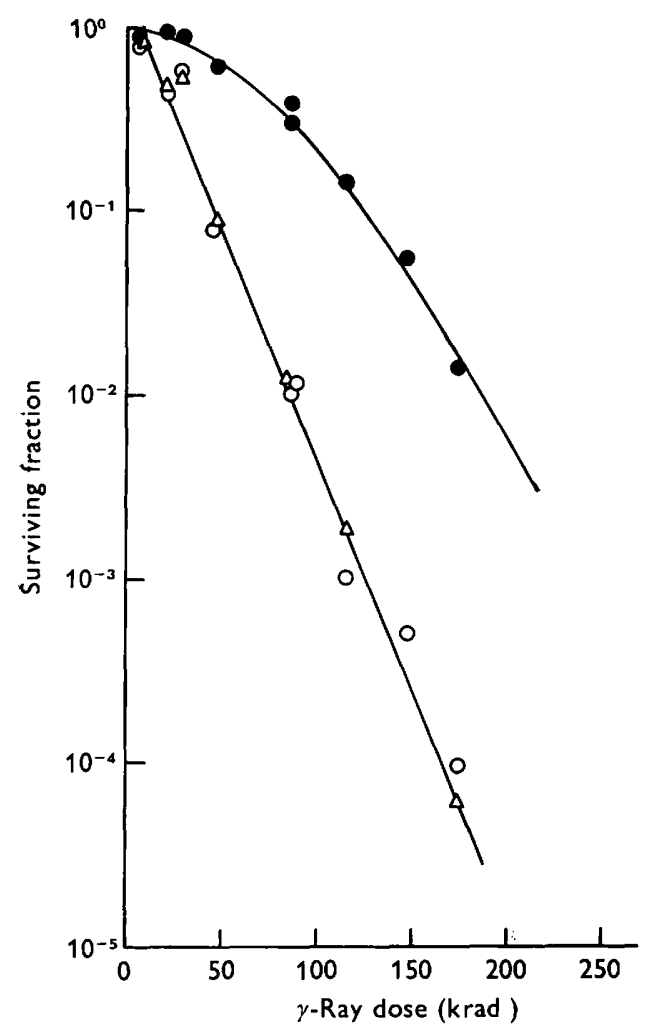

Fig. 3

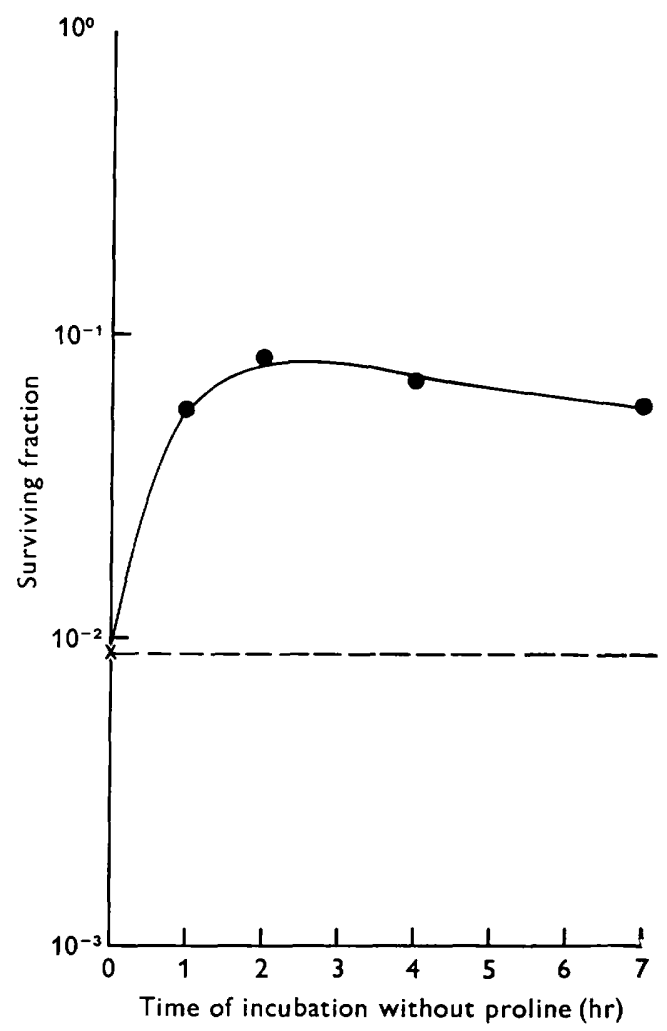

Fig. 4

Fig. 3. Survival of stationary phase Escherichia coli strain $\mathbf{B} / \mathbf{R}$ his $^{-}$after exposure to $\gamma$-rays under anaerobic conditions. $\mathbf{0}$, Survival of bacteria incubated throughout on medium $\mathrm{M}$ I9 +histidine. Minimum degree of survival of bacteria incubated on first medium before transfer to second medium:

$$
\begin{aligned}
& \text { Ist medium 2nd medium } \\
& \text { O } \quad \text { M } 19 \rightarrow M \text { 19+histidine } \\
& \triangle M_{19} \text { +histidine + chloramphenicol } \rightarrow M \text { I9+histidine }
\end{aligned}
$$

Fig. 4. Survival of stationary phase Escherichia coli strain $\mathbf{B} / \mathbf{R} 7$ (proline-requiring) after exposure to u.v. radiation $\left(215 \mathrm{ergs} / \mathrm{mm}^{2}\right)$. $\times$, Survival of bacteria incubated throughout on medium M $19+$ proline; - Survival of bacteria incubated on medium M 19 for the intervals indicated before transfer to medium $\mathrm{M}$ I9+ proline.

\section{Relationship between RNA synthesis and survival in irradiated Escherichia coli $B / R$}

Laevorphanol. This drug had no effect on the survival of irradiated Escherichia coli $B / R$ nor did it alter the extent of chloramphenicol-induced death. Very limited uptake of $\left[{ }^{14} \mathrm{C}\right]$ uracil into RNA took place initially in the u.v.-irradiated bacteria treated with 
laevorphanol (Fig. 6). The incorporation of $\left[{ }^{14} \mathrm{C}\right]$ leucine was commensurate with the uptake of labelled uracil into RNA. Thus in the presence of laevorphanol or chloramphenicol some RNA but no protein was synthesized.

Puromycin, chloramphenicol and amino-acid requiring auxotrophs. The uptake of $\left[{ }^{14} \mathrm{C}\right]$ uracil into u.v.-irradiated Escherichia coli $\mathrm{B} / \mathrm{R}$ in which protein synthesis was

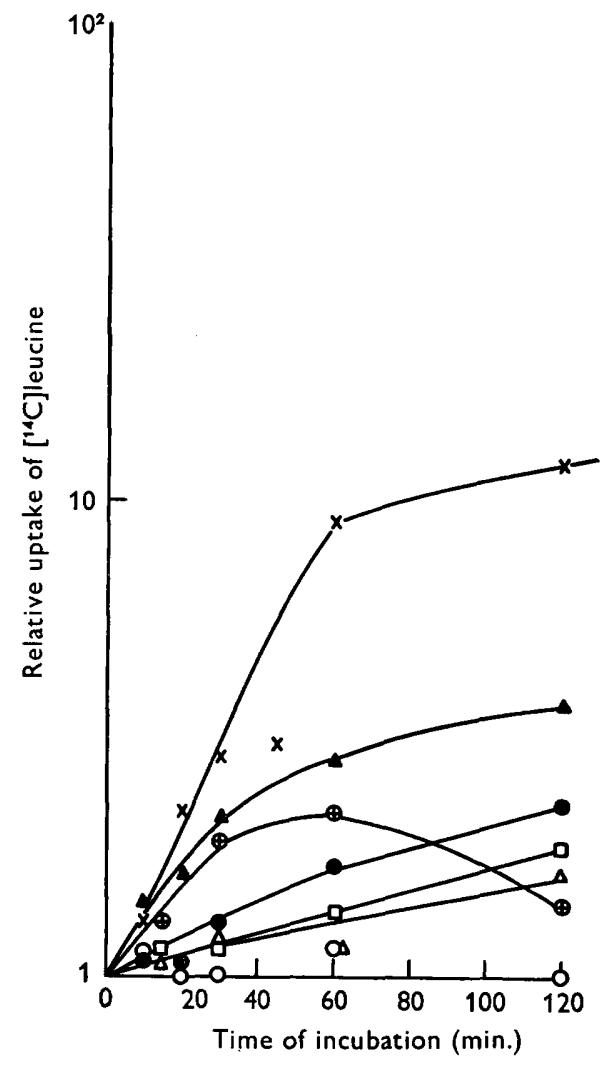

Fig. 5

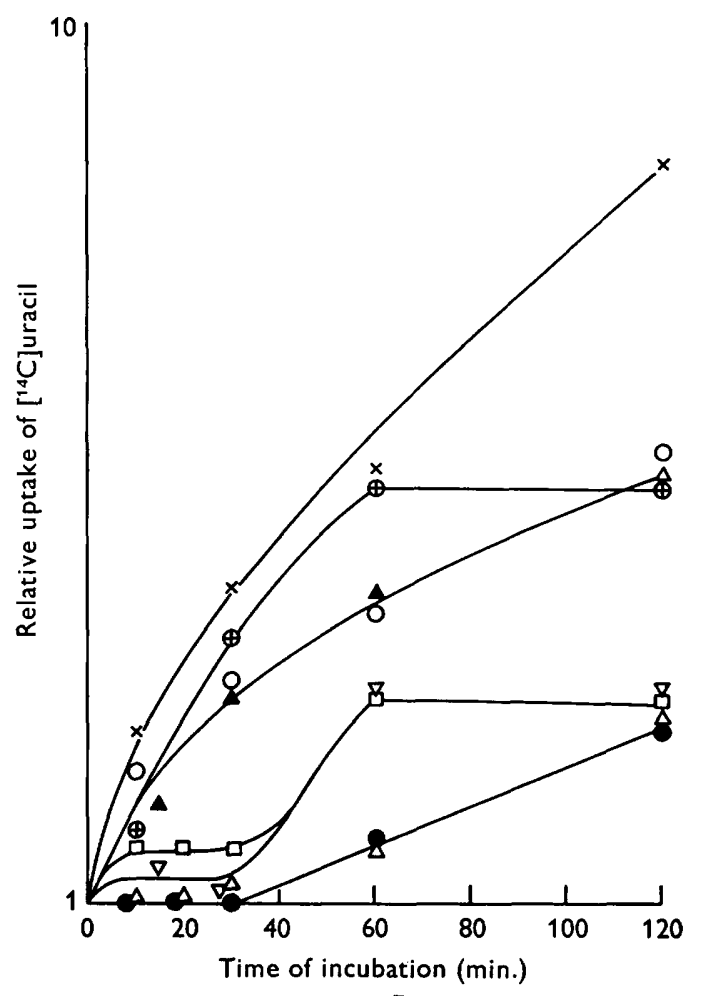

Fig."6

Fig. 5. Incorporation of $\left.{ }^{[4} \mathrm{C}\right]$ leucine into the acid-insoluble fraction of Escherichia coli strain $\mathrm{B} / \mathrm{R}$ after exposure to $\mathrm{U.v}$. radiation ( $190 \mathrm{ergs} / \mathrm{mm} .{ }^{2}$ ). $\times, E$. coli $\mathrm{B} / \mathrm{R}$ incubated in medium $\mathrm{M}$ I9; $O, E$. coli $\mathrm{B} / \mathrm{R}$ incubated in $\mathrm{M} 19+$ chloramphenicol; $\oplus, E$. coli $\mathrm{B} / \mathrm{R}$ incubated in $\mathrm{M} 19+$ puromycin; $\boldsymbol{\Delta}, E$. coli $\mathrm{B} / \mathrm{R}$ his- incubated in $\mathrm{M} 19$ lacking histidine; $\boldsymbol{O}, E$. coli $\mathrm{B} / \mathrm{R} 7$ incubated in $\mathrm{M} 19$ lacking proline; $\triangle, E$. coli $\mathrm{B} / \mathrm{R}$ trp- incubated in $\mathrm{M}$ i9 lacking tryptophan; $\square, E$. coli $\mathrm{B} / \mathrm{R}$ met $^{-}$incubated in $\mathrm{M}$ I9 lacking methionine.

Fig. 6. Incorporation of $\left[{ }^{14} \mathrm{C}\right.$ uracil into the acid-insoluble fraction of Escherichia coli strain $\mathrm{B} / \mathrm{R}$ after exposure to u.v. radiation ( $190 \mathrm{ergs} / \mathrm{mm}^{2}$ ). $\times, E$. coli $\mathrm{B} / \mathrm{R}$ incubated in medium M I9; $O, E$. coli $\mathrm{B} / \mathrm{R}$ incubated in $\mathrm{M} 19+$ chloramphenicol; $\oplus, E$. coli $\mathrm{B} / \mathrm{R}$ incubated in $\mathrm{M} 19+$ puromycin; $\nabla, E$. coli $\mathrm{B} / \mathrm{R}$ incubated in $\mathrm{M} \mathbf{1} 9+$ laevorphanol; $\boldsymbol{A}, E$. coli $\mathrm{B} / \mathrm{R}$ his incubated $^{-}$ in $\mathrm{M}$ I9 lacking histidine; $O, E$. coli $\mathrm{B} / \mathrm{R} 7$ incubated in $\mathrm{M}$ I9 lacking proline; $\triangle, E$. coli

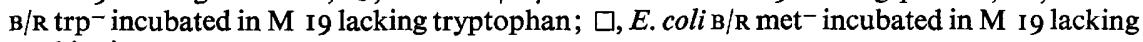
methionine.

inhibited or limited is also illustrated in Fig. 6. No uptake of radioactivity into RNA occurred in $E$. coli $\mathrm{B} / \mathrm{R} 7$ or $E$. coli $\mathrm{B} / \mathrm{R}$ trp- during the first $30 \mathrm{~min}$. of incubation in medium lacking proline or tryptophan respectively, and only a very small amount of 
incorporation took place into $E$. coli $\mathrm{B} / \mathrm{R}$ met $^{-}$during the same period in medium lacking methionine.

In contrast, when bacteria were treated with chloramphenicol or puromycin, or when histidine was withheld from the histidine-requiring auxotroph, RNA synthesis proceeded at a comparatively Although rapid rate. the rate and extent of synthesis was not so great as that in uninhibited cells, there was a 3- to 4-fold increase in the amount of RNA accumulating after $120 \mathrm{~min}$. incubation under these conditions. Qualitatively similar results were found for $\gamma$-irradiated cells.

\section{DISCUSSION}

Incubation of Escherichia coli $\mathrm{B} / \mathrm{R}$ with puromycin or chloramphenicol or incubation of $E$. coli $\mathrm{B} / \mathrm{R}$ his ${ }^{-}$without histidine all enhanced radiation killing. As some protein synthesis did occur in bacteria treated with puromycin or lacking histidine it would appear that the additional killing is not due entirely to abolition of protein synthesis immediately after irradiation. It is unlikely to result from insufficient synthesis of protein, perhaps required in an unknown repair process, since approximately the same limited amount of protein was synthesized in mutants requiring tryptophan, methionine or proline with no increase in killing. There is thus no direct correlation between the amount of protein synthesized and the survival of $E$. coli $\mathbf{B} / \mathbf{R}$ after irradiation.

There was, however, a definite correlation between conditions which allowed RNA synthesis to begin immediately after irradiation and those which enhanced death. Incubation with puromycin or chloramphenicol, or incubation of $E$. coli $\mathrm{B} / \mathrm{R}$ his- in the absence of added histidine, all allowed some RNA synthesis while the viable count was decreasing. Incubation of the tryptophan, methionine and proline mutants without their requirement, or of $E$. coli $\mathrm{B} / \mathrm{R}$ with laevorphanol, allowed little, if any, synthesis of RNA for at least $30 \mathrm{~min}$. and also had no effect on survival.

In conditions where no RNA synthesis took place, protein was still synthesized but at less than normal rate. When synthesis of both protein and RNA was stopped, during incubation of the bacteria with chloramphenicol + laevorphanol, enhanced killing occurred. Thus, even in the absence of RNA synthesis increased killing did occur when protein synthesis was inhibited at the same time, indicating a requirement for new protein to prevent further death among organisms unable to synthesize RNA.

Although we are unable to suggest a specific mechanism to account for the enhanced killing of irradiated Escherichia coli $\mathbf{B} / \mathbf{R}$, it is tempting to speculate that the phenomenon may be associated with the synthesis of an RNA component which is toxic to the bacteria. It seems reasonable to suggest that an abnormal messenger RNA could be synthesized on a DNA template which had been altered by exposure to u.v. radiation or to ionizing radiation and that this damage would be expressed if the abnormal RNA were involved in the synthesis of new protein.

One of us (A.J.F.) is indebted to the Medical Research Council for a studentship. 


\section{REFERENCES}

AlPER, T. (1963). Lethal mutations and cell death. Phys. Med. Biol. 8, 365.

ALPER, T. \& GILLIEs, N. E. (1958). Restoration of Escherichia coli strain B after irradiation: its dependence on suboptimal growth conditions. J. gen. Microbiol. 18, 46I.

AlPER, T. \& GILLIES, N. E. (1960). The relationship between growth and survival after irradiation of Escherichia coli strain B and two resistant mutants. J. gen. Microbiol. 22, I I3.

ForAGE, A. J. \& GILLIES, N. E. (1964). Restoration of Escherichia coli strain B after $\gamma$-irradiation. J. gen. Microbiol. 37, 33.

Gulles, N. E. (196I). The use of auxotrophic mutants to study restoration in Escherichia coli B after ultraviolet irradiation. Int. J. Radiat. Biol. 3, 379.

Grlues, N. E. \& Brown, D. (1967). A possible explanation of chloramphenicol death in irradiated Escherichia coli B/R. Biochem. biophys. Res. Commun. 26, 102.

JARDETZKY, O. \& JulIAN, G. R. (1964). Chloramphenicol inhibition of polyuridylic acid binding to E. coli ribosomes. Nature, Lond. $201,397$.

Miller, N. \& WilkInson, J. (1952). Actinometry of ionizing radiations. In Radiation Chemistry, Disc. Faraday Soc. no. 12, p. 50.

MorRis, A. J. \& SCHWEET, R. S. (196I). Release of soluble protein from reticulocyte ribosomes. Biochim. biophys. Acta 47, 415.

NomURA, M. \& Watson, J. D. (I959). Ribonucleoprotein particles within chloromycetin-inhibited Escherichia coli. J. molec. Biol. I, 204.

OKAGAKI, H. (1960). Effect of chloramphenicol on the survival in different strains of Escherichia coli irradiated with ultraviolet light. J. Bact. 79, 277.

Simon, E. J. (1963). Inhibition of synthesis of RNA in E. coli by the narcotic drug laevorphanol. Nature, Lond. 198, 794.

YARMOLINSKY, M. B. \& DE LA HABA, G. L. (I959). Inhibition by puromycin of amino acid incorporation into protein. Proc. natn. Acad Sci. U.S.A. 45, 721. 